\title{
The in vitro cytotoxic activity of ethno-pharmacological important plants of Darjeeling district of West Bengal against different human cancer cell lines
}

Bipransh K Tiwary ${ }^{1 \dagger}$, Sony Bihani ${ }^{2+}$, Anoop Kumar ${ }^{2}$, Ranadhir Chakraborty ${ }^{1}$ and Runu Ghosh ${ }^{1 *}$

\begin{abstract}
Background: Plant derived components have attracted particular attention as an alternative source to battle several diseases including cancer. The variation in the climate, the geographical location and the rich ethnomedicinal traditions has made the Darjeeling Himalayas an abode of invaluable repository of traditional medicinal plants. In this study, we explored the in vitro anticancer properties of traditionally used medicinal plants from the Darjeeling hills against different human cancer cell lines.

Methods: The ethanolic leaf extracts of 30 medicinal plants were tested for their cytotoxicity against human breast adenocarcinoma cell line (MCF 7), human hepatocarcinoma cell line ( $\left.\mathrm{HepG}_{2}\right)$ and human cervix adenocarcinoma cell line (HeLa). The cytotoxicity was evaluated by performing MTT assay, trypan blue exclusion assay and morphological assessment under phase contrast inverted microscope. For the extracts which tested positive, $\mathrm{IC}_{50}$ (the concentration that inhibited cell growth by 50\%) was calculated. The extract(s) were further subjected to Thin Layer Chromatography (TLC) to determine their phytochemical profile.
\end{abstract}

Results: Out of the 30 plant extracts tested, five plants, Artemisia indica, Eupatorium odoratum, Eupatorium adenophorum, Maesa macrophylla and Phlogacanthus thyrsiformis showed a > 50\% growth inhibition of cancer cell lines at a concentration of $50 \mathrm{\mu g} / \mathrm{ml}$. The sensitivity to different extracts varied according to the cell type under investigation. Of these plants, Maesa macrophylla, exhibited the most potent cytotoxicity against HeLa and MCF7 cell with IC 50 values of $9.55 \mu \mathrm{g} / \mathrm{ml}$ and $16.19 \mu \mathrm{g} / \mathrm{ml}$ respectively. Phytochemical analysis revealed the presence of coumarins, flavonoids, tannins, saponins, steroids and terpenes.

Conclusions: This is perhaps the first report of screening of traditional medicinal plants from Darjeeling district in West Bengal, India, for their cytotoxic activity against three human cancerous cell lines MCF7, HeLa and HepG2. The extracts of Maesa macrophylla significantly inhibited the growth of HeLa and MCF7 cancerous cell lines and constituted of multiple known biologically active compounds. The present study may provide the landmark for further exploration of M. macrophylla for its potent anticancer constituents.

Keywords: Darjeeling, Medicinal plants, Anticancer, Cytotoxicity, Phytochemicals

\footnotetext{
* Correspondence: runughoshdey@gmail.com

${ }^{\dagger}$ Equal contributors

'Omics Laboratory, Department of Biotechnology, University of North Bengal,

Raja Rammohunpur, Dist Darjeeling, West Bengal 734013, India

Full list of author information is available at the end of the article
} 


\section{Background}

Cancer stands second, after cardiovascular disorders, in the list of diseases responsible for maximum deaths in the world [1]. In 2008, the International Agency for Research on Cancer assessed that India represented about $8 \%$ of cancer deaths globally and about $6 \%$ of all deaths in India were due to cancer [2]. Recent studies have shown that the number of cancer deaths is increasing every year and the number is expected to increase further in future $[3,4]$. Despite the advancement in the cancer therapies which include chemotherapy and radiation therapy, the mortality rate associated with cancer has remained high. Thus, the present scenario and the toxic side effects associated with the available treatments calls for alternative methods, with higher efficacy and lesser noxious side effects, to deal with this disease. Plants have been looked upon as the best substitute and several have been evaluated in an effort to discover novel, potential anticancer compounds with no toxic effects $[5,6]$. In fact, several studies have elucidated the potential of a number of naturally derived phytochemicals as therapeutic agents against cancer. The first of these to advance into clinical use for the treatment of cancer were alkaloids, vinblastine and vincristine, isolated from the Madagascar periwinkle, Catharanthus roseus L. [7]. Others in this list includes Combretastatins obtained from Combretum caffrum [8], paclitaxel (Taxol), isolated from the Pacific yew, Taxus brevifolia [9] and homoharringtonine isolated from Cephalotaxus harringtonia [10]. In addition, numerous medicinal plants having anticancer properties have been identified [11].

Darjeeling district is situated in the northernmost part of the state of West Bengal in India that lies between $28^{\circ} 31^{\prime}-27^{\circ} 13^{\prime} \mathrm{N}$ latitude and $87^{\circ} 59^{\prime}-88^{\circ} 53^{\prime} \mathrm{E}$ longitude in the Eastern Himalayan region of India. The variation in altitude between hills and plains of Darjeeling that ranges between $150 \mathrm{~m}$ to $3636 \mathrm{~m}$, has led to diverse climatic conditions that supports one of the richest biodiversity in the world. Thus, this region houses a wealth of varied medicinal plants [12]. The ethnic communities of Darjeeling hills, major being Lepcha, Bhutia and Nepalese, still depend on plant-derived resources for primary health care needs. The socio-economic status has persuaded the development of affluent ethnomedicinal traditions in this region [13]. The diversity of the medicinal plants in the Darjeeling district has been well documented and studies have been done to evaluate antibacterial activity of some of these plants [14-16]. To the best of our knowledge, the ability of these traditional medicinal plants from Darjeeling for their cytotoxic activity against cancer cell lines has not been investigated. In this study, conceivably for the first time, an attempt was made to evaluate the in vitro cytotoxic activity of ethanolic extracts of 30 ethno-pharmacological important plants against three different human cancer cell lines and characterize the phytochemical constituents with the view of isolating compounds from these plants which may contribute to drug development against cancer.

\section{Methods}

Plant material and preparation of extracts

Fresh leaves of plants as listed in Table 1 were collected from Darjeeling district of West Bengal, India. The specimens were identified and the voucher specimens were assigned specific reference number (Table 1). The leaves were washed thoroughly, air-dried and crushed. The crushed samples were extracted with $95 \%$ ethanol $(1 \mathrm{~g}$ in $10 \mathrm{ml}$ ethanol) for $72 \mathrm{~h}$ at $37^{\circ} \mathrm{C}$ with occasional shaking. After $72 \mathrm{~h}$, the extract was filtered through a Whatman no. 1 filter paper and the filtrate was evaporated to dryness using a rotary evaporator (RV 10 Digital, IKA, Germany). The dried samples were stored at $-20^{\circ} \mathrm{C}$ until use.

\section{Human cell lines}

The human breast adenocarcinoma cell line (MCF 7), human hepatocarcinoma cell line $\left(\mathrm{HepG}_{2}\right)$ and human cervix adenocarcinoma cell line (HeLa) was obtained from National Centre for Cell Science, Pune, India. All cell lines were cultured in DMEM (Dulbecco's Modified Eagle Medium) supplemented with $10 \%$ fetal bovine serum (FBS), 100 units $/ \mathrm{ml}$ penicillin, $100 \mathrm{mg} / \mathrm{ml}$ streptomycin, $0.14 \%$ sodium bicarbonate and $0.1 \mathrm{mM}$ sodium pyruvate. The cell lines were maintained in $\mathrm{CO}_{2}$ incubator $\left(\mathrm{N}\right.$-Biotech) at $37^{\circ} \mathrm{C}$ in a $5 \% \mathrm{CO}_{2}$ atmosphere with 95\% humidity.

\section{In vitro cytotoxic activity}

Stock solutions at a concentration of $10 \mathrm{mg} / \mathrm{ml}$ were prepared by reconstituting the dried alcoholic extracts in dimethyl sulfoxide (DMSO, Hi-Media). The cytotoxic effect of each of the plant leaf extract was evaluated by tetrazolium- dye, MTT, assay $[17,18]$ with slight modifications. Briefly, the cancerous cells (MCF 7, HepG ${ }_{2}$ and HeLa) were seeded in 96-well plates at a density of $5 \times 10^{3}$ cells/well in $200 \mu \mathrm{l}$ culture medium. Following $24 \mathrm{~h}$ incubation and attachment, the cells were treated with different concentrations of extracts and similar concentration of diluents (DMSO) for further $24 \mathrm{~h}$. After treatment, media was replaced with MTT solution $(10 \mu \mathrm{l}$ of $5 \mathrm{mg} / \mathrm{ml}$ per well) prepared in PBS and incubated for $3 \mathrm{~h}$ at $37^{\circ} \mathrm{C}$ in a humidified incubator with $5 \% \mathrm{CO}_{2}$. The yellow MTT dye was reduced by succinate dehydrogenase in the mitochondria of viable cells to purple formazan crystals. To solubilize the formazan, $50 \mu \mathrm{l}$ of isopropanol was added to each well. The plates were gently shaken for $1 \mathrm{~min}$ and absorbance was measured at $600 \mathrm{~nm}$, with reference $490 \mathrm{~nm}$, by microtiter plate 
Table 1 List of plants screened for cytotoxicity with their ethnomedicinal uses in Darjeeling district*

\begin{tabular}{|c|c|c|c|c|c|c|c|}
\hline S. no. & Botanical name & $\begin{array}{l}\text { Voucher } \\
\text { number }\end{array}$ & Family & Local name & Type & Part used & Local medicinal uses \\
\hline 1 & Acmella calva (DC.) Jansen & DJ0092 & Asteraceae & Kalijhar & Herb & $\begin{array}{l}\text { Flower, } \\
\text { inflorescenc }\end{array}$ & Toothache, decay, mouth sore \\
\hline 2 & $\begin{array}{l}\text { Aconogonon molle (D. Don) } \\
\text { Hara }\end{array}$ & DJ0099 & Polygonaceae & Thotney & Shrub & Young shoot & Astringent \\
\hline 3 & Acorus calamus L. & DJ0049 & Araceae & Bojho & Herb & Root/Rhizome & $\begin{array}{l}\text { Vermifuge, fever antispasmodic, } \\
\text { Insect repellent Paste prepared } \\
\text { from dried or fresh rhizomes is } \\
\text { applied on forehead during fever. } \\
\text { Powder made fromdried rhizomes } \\
\text { is administered orally in case of } \\
\text { fever, bronchitis }\end{array}$ \\
\hline 4 & Artemisia indica Willd. & DJ0093 & Asteraceae & Titey pati & Herb & $\begin{array}{l}\text { Leaves \& Young } \\
\text { Shoot }\end{array}$ & $\begin{array}{l}\text { Use in Skin diseases, asthma, } \\
\text { anthelminthic, stomachic, } \\
\text { purgative, antispasmodic and } \\
\text { amoebic dysentery }\end{array}$ \\
\hline 5 & $\begin{array}{l}\text { Astilbe rivularis Buch.-Ham. } \\
\text { ex D. Don }\end{array}$ & DJ0077 & Saxifragaceae & Buriokahti & Herb & $\begin{array}{l}\text { Leaves/roots/ } \\
\text { Rhizome }\end{array}$ & $\begin{array}{l}\text { Diarrhea, dysentery, blood purifier } \\
\text { Root's juice or pieces are taken } \\
\text { orally during diarrhoea or dysentery }\end{array}$ \\
\hline 6 & Bauhinia vahlii Wight \& Arnott & DJ0091 & Caesalpiniaceae & Verla & Climber & Seeds bark leaves & $\begin{array}{l}\text { Seeds used as tonic, aphrodisiac, } \\
\text { leaves demulcent, bark is useful } \\
\text { in skin disease, diarrhea }\end{array}$ \\
\hline 7 & Bergenia ciliata (Haw.) Sternb. & DJ0076 & Saxifragaceae & Pakhanbed & Herb & Root \& rhizome & Tonic, fever, boils, astringent \\
\hline 8 & Callicarpa arborea Roxb. & DJ0090 & Lamiaceae & Guahelo & Shrub & Bark \& root & $\begin{array}{l}\text { The bark juice is given to treat } \\
\text { fever. The root is chewed in } \\
\text { cases of boils on the gums }\end{array}$ \\
\hline 9 & Cedrella toona & DJ0057 & Meliaceae & Toonee & Tree & $\begin{array}{l}\text { Bark, fruit, leaf, } \\
\text { flower }\end{array}$ & $\begin{array}{l}\text { It is useful in chronic dysentery, } \\
\text { ulcer, leprosy, cures fever, } \\
\text { headache, blood complaints, } \\
\text { cardiotonic, aphrodisiac, } \\
\text { anthelmentic; good for scabis } \\
\text { and expectorant }\end{array}$ \\
\hline 10 & $\begin{array}{l}\text { Cinchona succirubra Pav. } \\
\text { ex Klotzsch }\end{array}$ & DJ0096 & Rubiaceae & Kulain & Shrub & Trunk \& Stem bark & Malaria fever, neuralgia, sciatica \\
\hline 11 & Costus speciosus & DJ0102 & Costaceae & Betlaure & Herb & Root & $\begin{array}{l}\text { Useful in fever, bronchitis, anemia, } \\
\text { rheumatism and diabetic }\end{array}$ \\
\hline 12 & Dichroa febrifuga Lour. & DJ0073 & Hydrangeaceae & Basak & Shrub & Roots\& Leaves & Fever, malaria \\
\hline 13 & $\begin{array}{l}\text { Drymaria cordata (L.) Willd. } \\
\text { ex Schult }\end{array}$ & DJ0100 & Caryophyllaceae & Abhijal & Herb & Whole plant & $\begin{array}{l}\text { Above ground parts-steamed } \\
\text { and smelled during sinus trouble. } \\
\text { Plant paste for fever, cold and } \\
\text { cough also used for dog bites, } \\
\text { headache }\end{array}$ \\
\hline 14 & Equisetum debile Roxb. & DJ0071 & Equisetaceae & Kurkure Jhar & Herb & Aerial part & $\begin{array}{l}\text { Clotting agent used in wound, } \\
\text { nose bleeding \& bleeding of } \\
\text { urinary tract }\end{array}$ \\
\hline 15 & $\begin{array}{l}\text { Eupatorium adenophorum } \\
\text { Spreng./ } 6084\end{array}$ & DJ0054 & Asteraceae & Kalo banmara & Herb & Leaf & Uses in external cut and wound \\
\hline 16 & Eupatorium odoratum L. & DJ0089 & Asteraceae & Kalijhar & Herb & Aerial part & $\begin{array}{l}\text { Clotting agent used in wound, } \\
\text { nose bleeding \& bleeding of } \\
\text { urinary tract }\end{array}$ \\
\hline 17 & $\begin{array}{l}\text { Fagopyrum dibotrys (D. Don) } \\
\text { Hara }\end{array}$ & DJ0097 & Polygonaceae & Ban phapar & Herb & Fruit \& Grains & $\begin{array}{l}\text { Diet in colic, used in lungs } \\
\text { infection and pulmonary abscess }\end{array}$ \\
\hline 18 & $\begin{array}{l}\text { Hypericum uralum Buch.-Ham. } \\
\text { ex D.Don }\end{array}$ & DJ0072 & Hypericaceae & Urilo & Herb & $\begin{array}{l}\text { Shoot, flower \& } \\
\text { seeds }\end{array}$ & $\begin{array}{l}\text { Uses in wound and bruise. Also } \\
\text { used as Stimulant }\end{array}$ \\
\hline 19 & Maesa macrophyla & DJ0056 & Myrsinaceae & Boghati & & Bark, fruit, leaf & $\begin{array}{l}\text { Uses in tonsillitis, malarila fever, } \\
\text { scabis, diphtheria }\end{array}$ \\
\hline
\end{tabular}


Table 1 List of plants screened for cytotoxicity with their ethnomedicinal uses in Darjeeling district* (Continued)

\begin{tabular}{|c|c|c|c|c|c|c|c|}
\hline 20 & Mesua ferrea & DJ0091 & Nageeswari & Nageeswari & Shrub & Bark & $\begin{array}{l}\text { Uses various skin diseases } \\
\text { (mostly poxes)\& in menstrual } \\
\text { disorder }\end{array}$ \\
\hline 21 & Oscbekia nepalensis & DJ0083 & Melastomataceae & Angeri & Shrub & $\begin{array}{l}\text { Young leaf or } \\
\text { tender shoot }\end{array}$ & Pneumonia, fever, common cold \\
\hline 22 & $\begin{array}{l}\text { Phlogacanthus thyrsiformis } \\
\text { (Hardw.) Mabb. }\end{array}$ & DJ0095 & Acanthaceae & Chuwa & Shrub & $\begin{array}{l}\text { Leaf bark \& } \\
\text { inflorescence }\end{array}$ & $\begin{array}{l}\text { Liver cirrhosis, body ache, piles, } \\
\text { dysentery }\end{array}$ \\
\hline 23 & Pteris biaurita $\mathrm{L}$. & DJ0067 & Pteridaceae & $\begin{array}{l}\text { Thadey } \\
\text { unew }\end{array}$ & Herb & Stem, leaf stalk & $\begin{array}{l}\text { Bleeding and infection and } \\
\text { dysentery }\end{array}$ \\
\hline 24 & Rumex nepalensis Spreng. & DJ0081 & Polygonaceae & Halhaley & Herb & Root & $\begin{array}{l}\text { Root dried or fresh extract used } \\
\text { orally in hepatitis, loss of hair, } \\
\text { also plant used as dyes }\end{array}$ \\
\hline 25 & Selaginella monospora & DJ0059 & Selaginellaceae & & Shrub & Leaves & $\begin{array}{l}\text { Prevents cough, bleeding piles, } \\
\text { gravel aminorrhoea }\end{array}$ \\
\hline 26 & Smilax zeylanica L. & DJ0087 & Smilacaceae & Kukur & Shrub & Thorny climber & $\begin{array}{l}\text { Used in Urinary complaints and } \\
\text { dysentery Roots are taken as tonic }\end{array}$ \\
\hline 27 & Solanum torvum Sw. & DJ0066 & Solanaceae & Jungali bihi & Herb & Leaves & Toothache and jaundice \\
\hline 28 & Stephania glabra (Roxb.) Miers & DJ0086 & Menispermaceae & Taubarkey & Climber & Root bulb & $\begin{array}{l}\text { Powder used in diabetes, } \\
\text { tuberculosis, asthma, fever }\end{array}$ \\
\hline 29 & $\begin{array}{l}\text { Tetradium fraxinifolium (Hook.f.) } \\
\text { T.G. Hartley }\end{array}$ & DJ0082 & Rutaceae & Khanakpa & Tree & Fruits, leaves & $\begin{array}{l}\text { Gastritis, hepatic disorder, } \\
\text { dysentery, Indigestion, skin disease }\end{array}$ \\
\hline 30 & $\begin{array}{l}\text { Thysanolaena latifolia } \\
\text { (Roxb. ex Horn.) Honda }\end{array}$ & DJ0065 & Poaceae & Amliso & Shrub & $\begin{array}{l}\text { Young shoots \& } \\
\text { fresh root }\end{array}$ & $\begin{array}{l}\text { Tonsillitis, boils, abortion, mouth } \\
\text { wash skin diseases }\end{array}$ \\
\hline
\end{tabular}

*References [21-23,35].

reader (MIOS Junior, Merck). The percentage of cytotoxicity was calculated as $(\mathrm{Y}-\mathrm{X}) / \mathrm{Y} \times 100$, where $\mathrm{Y}$ is the mean optical density of control (DMSO treated cells) and $\mathrm{X}$ is the mean optical density of treated cells with plant extracts.

\section{Morphological assessment of cancerous cells}

Cells were seeded in $35 \mathrm{~mm}$ polyvinyl coated cell culture plates and allowed to attach at $37^{\circ} \mathrm{C}$ for $24 \mathrm{~h}$ in $\mathrm{CO}_{2}$ incubator. The following day, cells were treated with either $30 \mu \mathrm{g} / \mathrm{ml}$ plant leave extract or DMSO alone, serving as control, and incubated again at the same conditions. The morphological changes of cancerous cells under treated and control conditions were compared by monitoring with phase contrast inverted microscope (Olympus, CK40-SLP) at 200X magnification. The images were photographed at 8,16 , and $24 \mathrm{~h}$ of incubation.

\section{Trypan blue exclusion assay}

After morphological assessment, the cell viability was simultaneously assessed by Trypan blue dye exclusion assay [19]. For this, the cells were trypsinized with $0.25 \%$ trypsin-EDTA solution, resuspended in phosphate buffer saline (PBS) and stained with $0.4 \%$ Trypan blue dye solution ( $\mathrm{v} / \mathrm{v}$ in PBS). Within two minutes, the cells were loaded in a Neubauer chamber and the number of viable and non-viable cells per 1 x $1 \mathrm{~mm}$ square was counted under phase contrast microscope. The dead cells, because of losing the semi permeability of membrane, retained the blue dye and hence are coloured whereas viable or live cells remained unstained. The cells $/ \mathrm{ml}$ was calculated as average cell count $\mathrm{x}$ dilution factor $\mathrm{x} 10^{4}$ cells $/ \mathrm{ml}$. The $\%$ cell viability was determined as [(no. of viable cells/ total no. of viable + non-viable cells) $\times 100$. The percentage of growth inhibition was represented as (cell viability (control) - cell viability (with extract)\}.

\section{Thin layer chromatography (TLC) and phytochemical analysis}

Phytochemical screening by means of TLC was carried out for selected plants following the method of Wagner and Bladt [20]. For this, the dried extracts were reconstituted in ethanol to a concentration of $10 \mathrm{mg} / \mathrm{ml} .20 \mu \mathrm{l}$ of the extracts were spotted, in triplicate, on aluminiumbacked TLC plates (Merck, silica gel 60 F254). The chemical constituents were separated using any one of the three different eluent systems. For polar/neutral eluting system, solvents used were ethyl acetate/methanol/ water (40:5.4:5); for intermediate polarity/acidic elution, solvents ethyl acetate/formic acid/glacial acetic acid/ water (10:1.1:1.1:0.5) were used; and for non-polar/basic elution, hexane/ethyl acetate (3:1) solvents were used. The TLC plates were dried under a stream of cold air until there was no solvent smell remaining to ensure complete removal of the eluting solvents. The plates were examined under UV light (365 nm) to detect 
coumarins that appear as blue, violet or yellow fluorescent spots. The specific groups present in the extracts were identified using specific developers. Vanillinsulphuric acid spray reagent ( $0.1 \mathrm{~g}$ vanillin: $28 \mathrm{ml}$ methanol:1 ml sulphuric acid) were then sprayed on the dried plates and heated at $110^{\circ} \mathrm{C}$ for colour development for detecting the presence of monoterpene alcohol, bitter principle and saponin. Sprinkling the plates with 5\% ethanolic solution of aluminum Chloride $\left(\mathrm{AlCl}_{3}\right)$ resulting in the appearance of yellow or greenish fluorescent spot under UV light at $365 \mathrm{~nm}$ indicated the presence of flavonoids. A brown or yellowish coloration with LiebermanBurchard's reagent reveals the presence of triterpenes and steroids. A $10 \%$ vanillin ethanol solution was used for detecting saponins, the presence of which results in blue, violet and sometimes yellow spots. Using a $2 \%$ ferric chloride solution, development of chestnut, violet, green and blue colour reveals the presence of polyphenols, whereas a bluish or greenish black colour would indicate a positive test for tannins.

\section{Statistical analysis}

Results were presented as Mean \pm SD of triplicates from three independent experiments. To calculate the concentration required to produce $50 \%$ reduction in cell viability $\left(\mathrm{IC}_{50}\right)$ regression analysis was performed using Microsoft Excel 2010. Data were analyzed and compared by one-way analysis of variances (ANOVA) by using the software SPSS 15.0 for windows (SPSS Inc. Chicago, IL, USA) and differences with $\mathrm{p}<0.05$ were considered significant.

\section{Results and discussion}

The medicinal plants are the most sought after substitutes as the source of antimicrobial and anticancer chemotherapeutic agents. The use of traditional medicinal plants for varied ailments by different ethnic groups of Darjeeling district has been aptly recognized and it has been suggested that cures for diseases like cancer; AIDS, etc. may lay hidden in this wealth of folklore medicinal plants $[13,21,22]$. We collected 30 plants that have been reported to be used as cure for a wide range of diseases as has been summarized in Table 1, with the aim to uncover their cytotoxic properties. Recent reports have shown that cancer frequency in West Bengal has drastically increased and the most frequently affected organs included breast, cervix, lung, liver and pancreas [23]. Thus, for screening studies, we used three human cancerous cell lines, MCF7 (breast adenocarcinoma), $\mathrm{HepG}_{2}$ (hepatocarcinoma) and HeLa (cervix adenocarcinoma), as high rates of these specific cancers were noted in West Bengal. Several studies on screening various folklore medicinal plants to identify their cytotoxic activity against human carcinoma cell lines have been reported [24-27].
Ethanolic leaf extract of each of the listed plants were screened for their cytotoxicity against the three cancer cell lines at a single dose of $50 \mu \mathrm{g} / \mathrm{ml}$. Our aim was to consider only those plants which exhibited a potent cytotoxic activity $(\sim 50 \%)$ and to meet this need we assessed the growth inhibitory activity of $50 \mu \mathrm{g} / \mathrm{ml} \mathrm{of}$ each extract at an incubation period of $24 \mathrm{~h}$. Preliminary screening results showed that the extent of inhibition varied between the types of cell lines and also the types of extract used. Out of the 30 extracts tested, 9 had almost no effect $(<10 \%)$ on the growth of any of the three cell lines (Table 2). An inhibition of $<50 \%$ and $>11 \%$ (moderate cytotoxic activity) of 11 plant extracts against HeLa cells, 6 plant extracts against $\mathrm{HepG}_{2}$ cells and 2 plant extracts against MCF7 cells was observed. From the total of 30 plant extracts, only five showed $>50 \%$ cytotoxic activity against the different cancerous cell lines at a concentration of $50 \mu \mathrm{g} / \mathrm{ml}$ after $24 \mathrm{~h}$ incubation. The possibility that the other plant extracts may also show greater inhibitory activity at either higher concentration or prolonged incubation cannot be ruled out. Nevertheless, we set stringent conditions to identify extracts exhibiting highly potential and effective cytotoxicity. In a nutshell, results of our study implicated that the human cervix adenocarcinoma cell line (HeLa) was sensitive while the other two cell lines, human breast adenocarcinoma (MCF7) and human hepatocarcinoma cell line $\left(\mathrm{HepG}_{2}\right)$ were comparatively resistant to cytotoxicity of the tested extracts. Similarly, while screening plants used in Thai folklore medicine for cytotoxic activity, Mahavorasirikul et al. observed that sensitivity towards the tested extracts was dependent on the type of cancer cell line used and $\mathrm{HepG}_{2}$ appeared to be the most resistant cell line [27]. In addition, it may also be hypothesized that the variation may be due to the tissue specificity of different components present in the extract [28].

Of the five potential plant extracts, three, Artemisia indica (P4), Maesa macrophylla (P19) and Phlogacanthus thyrsiformis (P22) could inhibit the growth of HeLa and MCF7 cells. The extent of inhibition by P4 and P22 was in the range of 50 to $60 \%$. On the other hand, P19, showed $\sim 75$ to $80 \%$ growth inhibition of both the cell lines. The extract of Eupatorium odoratum (P16) was cytotoxic to $\mathrm{HepG}_{2}$ (53.11 $\pm 4.87 \%$ inhibition) and HeLa $(78.03 \pm 1.63)$ cells, whereas Eupatorium adenophorum (P15) could inhibit the growth of only HeLa cells by $\sim 61 \%$ (Table 2). Thus, these five plants were considered to possess potent activity against at least one cancer cell line. The cytotoxicity was also assessed simultaneously at different time points by observing the cells under phase contrast microscope and estimating the $\%$ inhibition in growth using Trypan blue dye exclusion assay. The results represented in Figures 1 and 2 
Table 2 Percentage inhibition in the growth of HeLa, HepG2 and MCF7 cancer cell lines in the presence of $50 \mu \mathrm{g} / \mathrm{ml}$ of ethanolic extracts of leaves of the plants

\begin{tabular}{|c|c|c|c|c|}
\hline S. no. & Plant name & HepG2 & Hela & MCF7 \\
\hline 1 & Acmella calva & 0 & $2.95 \pm 0.81$ & 0 \\
\hline 2 & Aconogonon molle & 0 & $4.91 \pm 1.25$ & 0 \\
\hline 3 & Acorus calamus L. & $0.23 \pm .04$ & 0 & 0 \\
\hline 4 & Artemisia indica & $44.61 \pm 1.9$ & $59.34 \pm 0.28$ & $58.869 \pm 0.25$ \\
\hline 5 & Astilbe rivularis & $49.34 \pm 1.5$ & 0 & 0 \\
\hline 6 & Bauhinia vahlii & 0 & $35.08 \pm 2.68$ & 0 \\
\hline 7 & Bergenia ciliata & $27.14 \pm 4.8$ & $6.23 \pm 2.3$ & 0 \\
\hline 8 & Callicarpa arborea. & 0 & $23.93 \pm 2.96$ & 0 \\
\hline 9 & Cedrella toone & 0 & $28.52 \pm 3.3$ & 0 \\
\hline 10 & Cinchona succirubra & 0 & 0 & 0 \\
\hline 11 & Cortus speciosus & 0 & $47.87 \pm 1.2$ & $1.32 \pm 0.6$ \\
\hline 12 & Dichroa febrifuga & 0 & 0 & $19.55 \pm 0.67$ \\
\hline 13 & Drymaria cordata L. & 0 & 0 & 0 \\
\hline 14 & Equisetum debile & 0 & $15.73 \pm 2.3$ & 0 \\
\hline 15 & $\begin{array}{l}\text { Eupatorium } \\
\text { adenophorum }\end{array}$ & 0 & $60.98 \pm 1.7$ & 0 \\
\hline 16 & Eupatorium odoratum L. & $53.11 \pm 4.87$ & $78.03 \pm 1.63$ & $23.82 \pm 5.35$ \\
\hline 17 & Fagopyrum dibotrys & 0 & $35.74 \pm 0.98$ & 0 \\
\hline 18 & Hypericum uralum & 0 & 0 & 0 \\
\hline 19 & Maesa macrophylla & $24.31 \pm 3.1$ & $80.98 \pm 1.2$ & $74.33 \pm 0.16$ \\
\hline 20 & Mesua ferrea & $3.54 \pm 0.9$ & 0 & 0 \\
\hline 21 & Oscbekia nepalensis & 0 & $1.63 \pm 0.84$ & 0 \\
\hline 22 & $\begin{array}{l}\text { Phlogacanthus } \\
\text { thyrsiformis }\end{array}$ & 0 & $58.03 \pm 4.2$ & $52.34 \pm 1.8$ \\
\hline 23 & Pteris biaurita $\mathrm{L}$. & $34.23 \pm 3.0$ & $46.56 \pm 0.35$ & 0 \\
\hline 24 & Rumex nepalensis & 0 & $41.97 \pm 1.34$ & 0 \\
\hline 25 & Seleginella monospora & 0 & 0 & 0 \\
\hline 26 & Smilax zeylanica L. & 0 & $33.44 \pm 0.35$ & 0 \\
\hline 27 & Solanum torvum & 0 & $11.14 \pm 1.2$ & 0 \\
\hline 28 & Stephania glabra & 0 & $14.75 \pm 2.5$ & 0 \\
\hline 29 & Tetradium fraxinifolium & 0 & 0 & 0 \\
\hline 30 & Thysanolaena latifolia & $29.50 \pm 3.9$ & 0 & 0 \\
\hline
\end{tabular}

Data are presented as mean \pm SD from three independent experiments, each run in triplicate. The \% inhibition was calculated as percent difference between growth in DMSO (control) and growth in the presence of extracts after $24 \mathrm{~h}$ of incubation (treated).

clearly show the growth inhibitory effect in both HeLa and MCF7 cell lines in the presence of Maesa macrophylla extract. In contrast, a substantial inhibition was not detected when M. macrophylla leaf extract was used against $\mathrm{HepG}_{2}$ cells (Additional file 1). The results observed with the other four extracts also matched with that obtained using MTT assay (data not shown).

The five promising plant extracts obtained after the first screening were further assessed for their $\mathrm{IC}_{50}$ (dose that inhibits cell growth by $50 \%$ ) values at the concentration range of $50 \mu \mathrm{g}, 40 \mu \mathrm{g}, 30 \mu \mathrm{g}, 20 \mu \mathrm{g}$, and $10 \mu \mathrm{g}$. To determine the concentration of the plant extracts that caused a $50 \%$ reduction in cell viability $\left(\mathrm{IC}_{50}\right)$, regression analysis was done. The results obtained are tabulated in Table 3. The $\mathrm{IC}_{50}$ value of Artemisia indica was found to be $48 \mu \mathrm{g} / \mathrm{ml}$ for both HeLa and MCF7 cell lines. Earlier studies have demonstrated antimicrobial, cytotoxic and antioxidant activities of essential oil from the aerial parts of Artemisia indica [29]. An $\mathrm{IC}_{50}$ value of $32 \mu \mathrm{g} / \mathrm{ml}$ for HeLa cells and $50 \mu \mathrm{g} / \mathrm{ml}$ for $\mathrm{HepG}_{2}$ was obtained with the extract of Eupatorium odoratum. The ability of acetone and ethyl acetate extracts of leaves of Eupatorium odoratum to induce cell death in MCF7 and Vero cell lines have previously been reported [30]. In our studies, we did not observe cytotoxicity of $E$. odoratum against MCF7 perhaps because we used ethanol as the extracting solvent. Phlogacanthus thyrsiformis is an evergreen shrub (vasaka in hindi) that has been reported to have antimicrobial, analgesic and free radical scavenging properties [31-33]. Our studies revealed cytotoxic activity of $P$. thyrsiformis with $\mathrm{IC}_{50}$ value of $\sim 50 \mu \mathrm{g} / \mathrm{ml}$ for two cancer cell lines HeLa and MCF7. Eupatorium adenophorum showed an $\mathrm{IC}_{50}$ value of $42 \mu \mathrm{g} / \mathrm{ml}$ against HeLa cell lines. The antioxidant activity of essential oil of $E$. adenophorum has earlier been reported [34].

Among the five plants, Maesa macrophylla showed the most promising inhibitory effect at $24 \mathrm{~h}$ incubation with $\mathrm{IC}_{50}$ value of $22.45 \mu \mathrm{g} / \mathrm{ml}$ and $22.66 \mu \mathrm{g} / \mathrm{ml}$ for HeLa and MCF7 cell lines respectively. Maesa macrophylla, belonging to family Myrsinaceae, is found in West Bengal and Uttar Pradesh in India. The bark of the plant is used to treat tonsillitis, the juice of the fruit is applied to treat scabies and the leaves are used to treat fever and boils. The bark of the plant has been reported to possess antimicrobial and antiviral activity [35]. Studies on chemical components of $M$. macrophylla leaves have revealed the presence of a novel quinone [36]. However, detailed analysis of bioactive properties of this plant has not yet been reported. According to the US National Cancer Institute Plant Screening Program, a crude extract is generally considered to have in vitro cytotoxic activity against carcinoma cells, if the $\mathrm{IC}_{50}$ value at an incubation period between 48 and 72 hours, is less than $20 \mu \mathrm{g} / \mathrm{ml}$ [37]. Based on these criteria, we further evaluated the cytotoxic effects of Maesa macrophylla at $72 \mathrm{~h}$ of incubation. Our results revealed an $\mathrm{IC}_{50}$ of $9.55 \mu \mathrm{g} / \mathrm{ml}$ for HeLa and $16.19 \mu \mathrm{g} / \mathrm{ml}$ for MCF7 cell line (Figure 3). Hence, it follows that, out of the 30 plants screened for their cytotoxicity, only the leaf extract from Maesa macrophylla promises to have a high level of cytotoxicity against human breast adenocarcinoma, MCF7 and cervix adenocarcinoma, HeLa cell lines. In a recent report, 
$\mathbf{A}$

$\mathbf{0 h}$
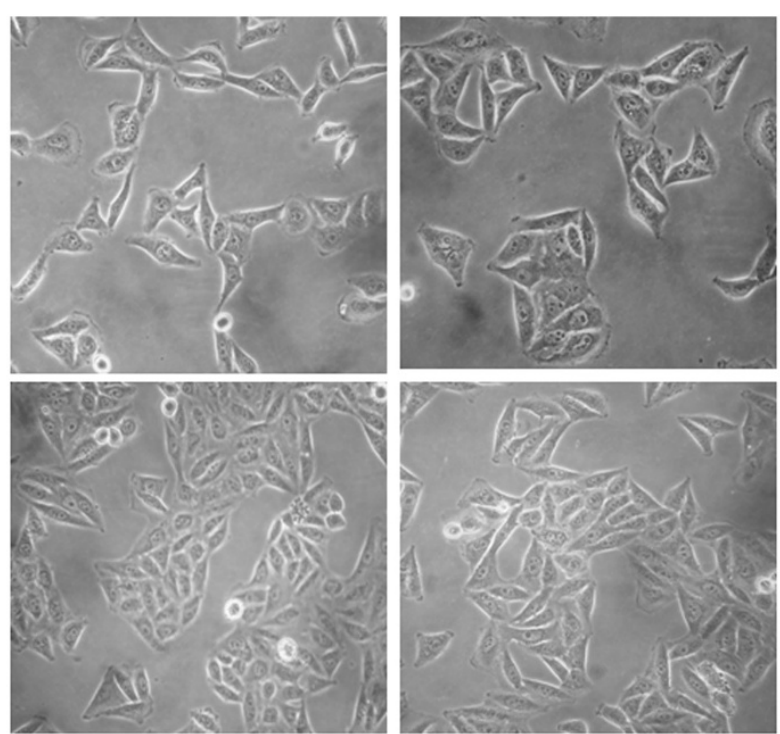

$8 \mathbf{h}$
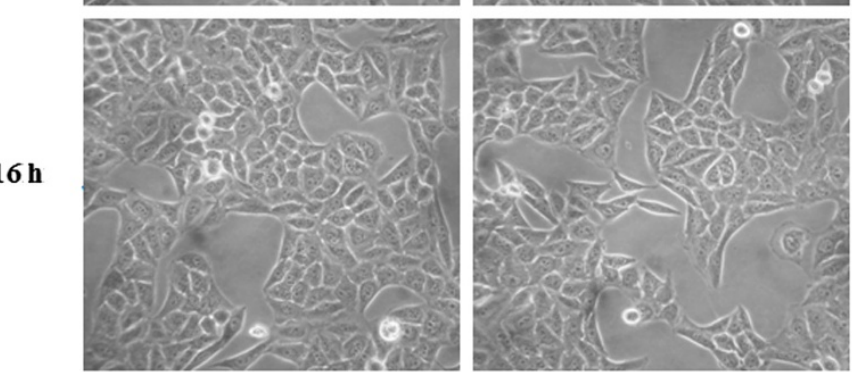

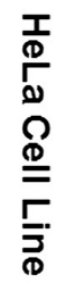

$24 \mathrm{~h}$

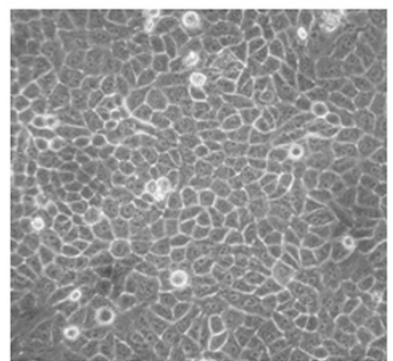

Control

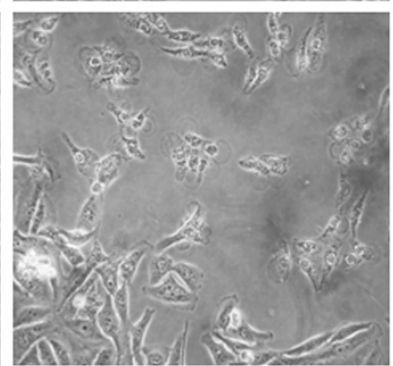

Treated

B

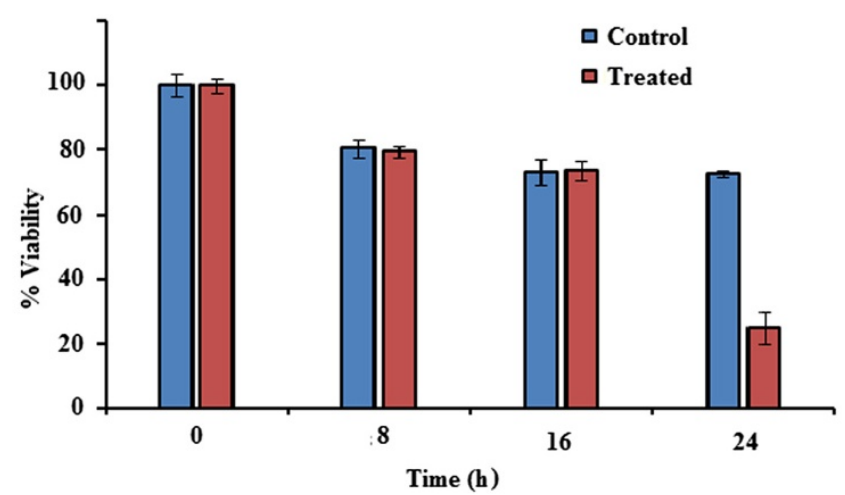

Figure 1 Time dependent effect of $30 \mu \mathrm{g} / \mathrm{ml}$ of $M$. macrophylla leaf extract on the proliferation of HeLa, human cervix adenocarcinoma, cell line. The cells were incubated either with DMSO (control) or the extract (treated) and (A) observed under phase contrast microscope; and (B) \% inhibition in growth was quantified based on Trypan blue dye exclusion assay; at different time points. 
A

$8 \mathrm{~h}$
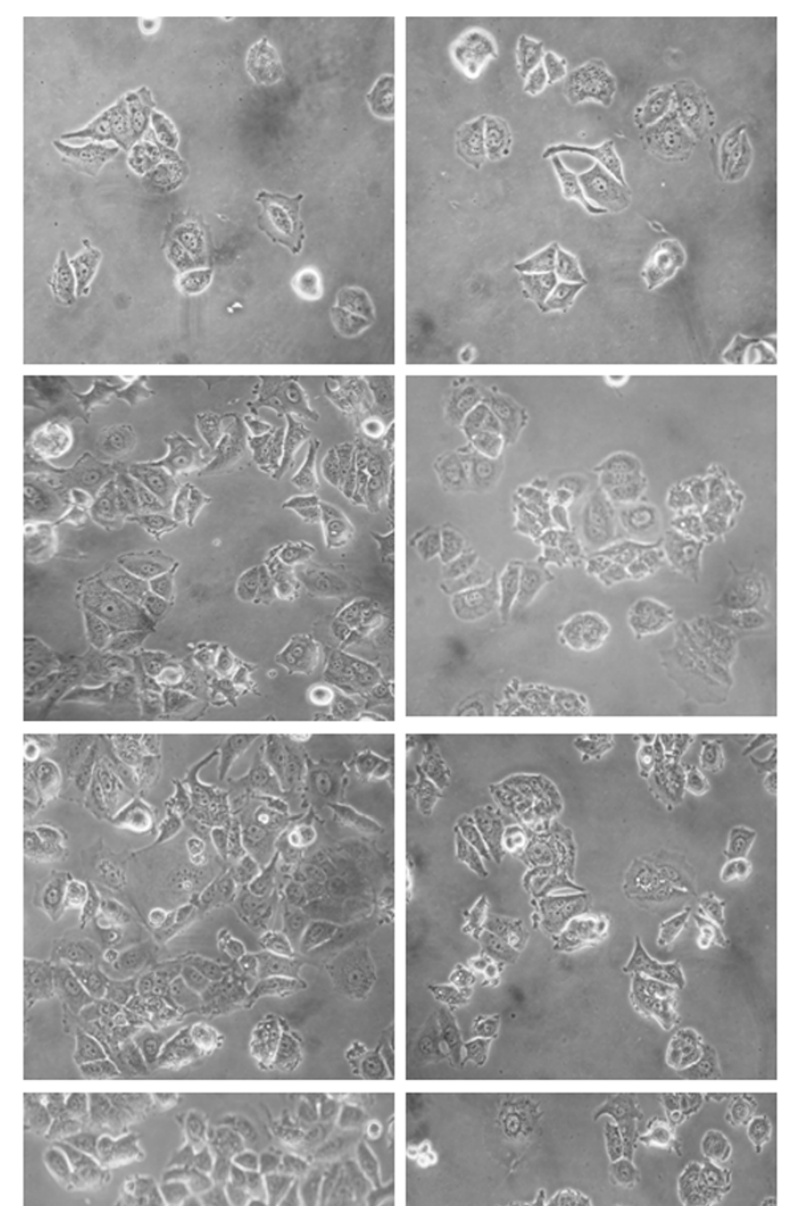

24 h

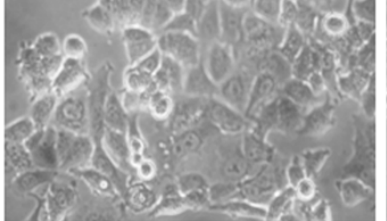

Control

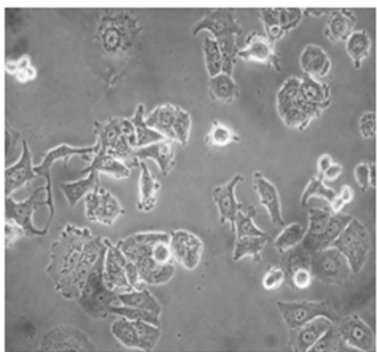

Treated

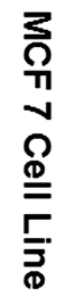

\section{B}

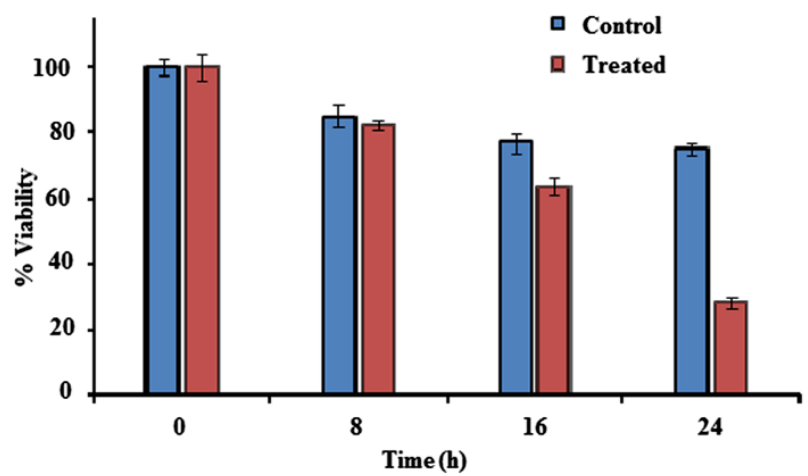

Figure 2 Time dependent effect of $30 \mu \mathrm{g} / \mathrm{ml}$ of $M$. macrophylla leaf extract on the proliferation of MCF7, human breast adenocarcinoma, cell line. (A) observed under phase contrast microscope (B) \% inhibition in growth was quantified based on Trypan blue dye exclusion assay. 
Table 3 Cytotoxic activity expressed as $\mathrm{IC}_{50}(\mu \mathrm{g} / \mathrm{ml})$ of extracts of five selected plants

\begin{tabular}{llll}
\hline Plant & HeLa & Hep G2 & MCF-7 \\
\hline Artemisia indica & $48 \pm 0.6$ & $>50$ & $48 \pm 1.2$ \\
Eupatorium adenophorum & $42 \pm 1.49$ & $\mathrm{ND}$ & $\mathrm{ND}$ \\
Eupatorium odoratum & $32 \pm 3.8$ & $50 \pm 0.9$ & $\mathrm{ND}$ \\
Maesa macrophylla & $22.45 \pm 2.5$ & $\mathrm{ND}$ & $22.66 \pm 1.6$ \\
Phlogacanthus thyrsiformis & $46.7 \pm 1.3$ & $\mathrm{ND}$ & $49 \pm 0.4$ \\
\hline
\end{tabular}

Data are presented as mean \pm SD from three independent experiments, each run in triplicate. $\mathrm{IC}_{50}$ was calculated after exposing the cells to the extracts for $24 \mathrm{~h}$.

ND- Not determined.

Fadeyi et al. demonstrated that among the twenty four traditionally used Nigerian medicinal plants, one plant exhibited potent cytotoxic activity against five different cancer cell lines including MCF7 (26).

Phytochemicals are considered as active medicinal chemical constituents of plants [38]. To analyse the presence of different constituents in leaves of $M$. macrophylla, the extract was subjected to TLC and detected using specific reagents [39]. The results revealed the presence of various medicinally important phytochemicals such as coumarins, flavonoids, tannins, saponins, terpenes and steroids (Table 4). All these bioactive components have been shown to possess anti cancer properties. For example, Genistein, a coumarin derivative and a natural component of soy, prevents breast and prostate cancers in animal models [40]. Diosgenin, a naturally occurring steroid; fisetin, a flavonoid present in apples and strawberries; and triterpenoids, found in various plants have been shown to inhibit breast cancer [41-43]. The ability of saponins and tannins to exhibit cytotoxic properties also has been reported earlier $[44,45]$. The isolation of

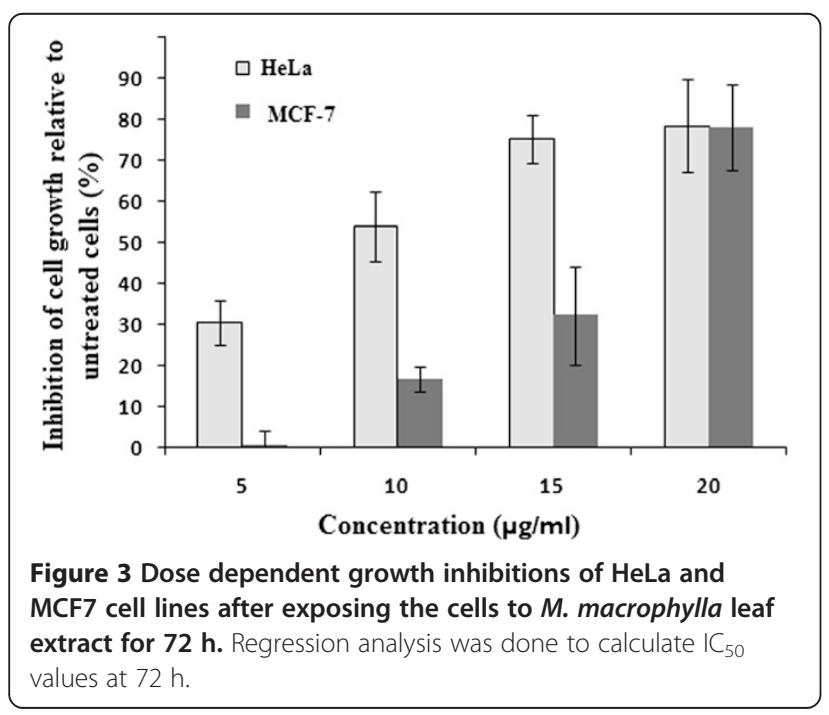

Table 4 Qualitative analysis of phytochemicals in Maesa macrophylla leaf extract

\begin{tabular}{|c|c|c|c|}
\hline Phytochemical & Detection system & Observation & Result \\
\hline Coumarin & $365 \mathrm{~nm}$ & Blue spot & + \\
\hline Flavonoids & $5 \% \mathrm{AlCl}_{3}$ & Yellow spot & + \\
\hline Tannin & $2 \% \mathrm{FeCl}_{3}$ & $\begin{array}{l}\text { Greenish Black } \\
\text { spot }\end{array}$ & + \\
\hline Saponin & $\begin{array}{l}10 \% \text { Vanillin } \\
\text { (Ethanol) }\end{array}$ & $\begin{array}{l}\text { Violet and } \\
\text { yellow }\end{array}$ & + \\
\hline $\begin{array}{l}\text { Monoterpene alcohol, } \\
\text { Bitter principle saponin }\end{array}$ & Vanillin- $\mathrm{H}_{2} \mathrm{SO}_{4}$ & Blue & + \\
\hline Triterpene and steroid & $\begin{array}{l}\text { Lieberman-Buchard's } \\
\text { reagent }\end{array}$ & $\begin{array}{l}\text { Brown and } \\
\text { yellow spots }\end{array}$ & + \\
\hline
\end{tabular}

+ tested positive for phytochemicals.

different constituents from Maesa macrophylla and evaluating their anticancer properties are underway.

\section{Conclusions}

This is perhaps the first study that deals with the screening of plants from Darjeeling hills for their cytotoxic activity against cancerous cell lines. The outcome of the present study indicates that five out of the thirty plants tested, exerted a $>50 \%$ growth inhibitory effect on HeLa, MCF7 and $\mathrm{HepG}_{2}$ cancer cells. The level of inhibition was different for different cell lines and none of the extract could inhibit all the three cancer cell lines under investigation. Only one plant, Maesa macrophylla, showed a highly promising cytotoxic activity against HeLa $\left(\mathrm{IC}_{50} 9.55 \mu \mathrm{g} / \mathrm{ml}\right)$ and MCF7 ( $\left.\mathrm{IC}_{50} 16.19 \mu \mathrm{g} / \mathrm{ml}\right)$ cell lines. Phytochemical analysis revealed the presence of multiple medicinally active compounds. Identifying the active compound(s) and comparing its cytotoxicity with known anticancer compounds is in progress.

\section{Additional file}

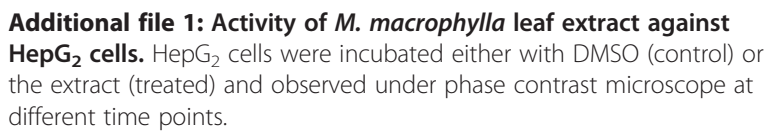

\section{Competing interests}

The authors declare that they have no competing interests.

\section{Authors' contributions}

Conceived and designed the experiments: RG, RC and AK. Performed the experiments: BKT and SB. Analyzed the data: RG, RC and AK. Contributed to the writing of the manuscript: $R G, R C, A K$ and BKT. Generated the figures: BKT and AK. All authors read and approved the final manuscript.

\section{Acknowledgements}

This study was funded by the Department of Biotechnology, Government of India (BT/Bio-CARe/06/141/2010-11). Authors are thankful to Prof. A P Das, Department of Botany, University of North Bengal, for identifying the plant specimens. The contribution of Mr Sourav Moktan, Researcher of the same Department in identification and collection of plants is also acknowledged. 


\section{Author details}

1Omics Laboratory, Department of Biotechnology, University of North Bengal, Raja Rammohunpur, Dist Darjeeling, West Bengal 734013, India. ${ }^{2}$ ANMOL Laboratory, Department of Biotechnology, University of North Bengal, Raja Rammohunpur, Dist Darjeeling, West Bengal 734013, India.

\section{Received: 21 October 2014 Accepted: 29 January 2015} Published online: 07 February 2015

\section{References}

1. Jemal A, Siegel R, Ward E, Murray T, Xu J, Thun MJ. Cancer statistics. CA Cancer J Clin. 2007;57:43-66.

2. Ferlay J, Shin HR, Bray F, Forman D, Mathers C, Parkin D. Estimates of worldwide burden of cancer in 2008: GLOBOCAN 2008. Int J Cancer. 2010;127:2893-917.

3. Dikshit R, Gupta PC, Ramasundarahettige C, Gajalakshmi V, Aleksandrowicz $\mathrm{L}$, Badwe $\mathrm{R}$, et al. Cancer mortality in India: a nationally representative survey. Lancet. 2012;379:1807-16.

4. Ali I, Wani WA, Saleem K. Cancer scenario in India with future perspectives. Canc Ther. 2011;8:56-70.

5. Gullett NP, Ruhul Amin AR, Bayraktar S, Pezzuto JM, Shin DM, Khuri FR, et al. Cancer prevention with natural compounds. Semin Oncol. 2010;37:258-81.

6. Shah U, Shah R, Acharya S, Acharya N. Novel anticancer agents from plant sources. Chin J Nat Med. 2013;11(1):16-23.

7. Cragg GM, Newman DJ. Plant as source of anticancer agents. J Ethnopharmacol. 2005;100:72-9.

8. Cirla A, Mann J. Combrestatins: from natural product to drug discovery. Nat Prod Rep. 2003;20:558-64.

9. Luduena RF. Multiple form of tubulin: different gene products and covalent modification. Int Rev Cytology. 1998;178(13):207-75.

10. Itokawa H, Wang X, Lee K-H. Homoharringtonine and related compounds. In: Cragg GM, Kingston DGI, Newman D, editors. Anticancer agents from natural products. Boca Raton: Florida, Brunner-Routledge Psychology Press, Taylor \& Francis Group; 2005. p. 47-70.

11. Sultana S, Asif HM, Nazar HMl, Akhtar N, Rehman JU, Rehman RU. Medicinal plants combating against cancer - a green approach. Asian Pac J Cancer Prev. 2014;15(11):4385-94.

12. Yonzone R, Bhujel RB, Rai S. Genetic resources, current ecological status and altitude wise distribution of medicinal plants diversity of Darjeeling Himalaya of West Bengal, India. Asian Pac J Trop. 2012;S439-S445.

13. Chhetri DR, Basnet D, Chiu PF, Kalikotay S, Chhetri G, Parajuli S. Current status of ethnomedicinal plants in the Darjeeling Himalaya. Curr Sci. 2005;89:265-8

14. Yonzone R, Rai S, Bhujel RB. Ethnomedicinal and aromatic plant diversity and resources of Darjeeling district of Eastern Himalaya in India. Int J Adv Pharmaceut Res. 2012;3(4):859-71.

15. Rai A, Rai S, Yonzone R. Ethnomedicinal plants used by the people of Darjeeling hills in the Eastern Himalaya of India. Univ J Pharm. 2013;02(01):122-34.

16. Sharma BC. In vitro antibacterial activity of certain folk medicinal plants from Darjeeling Himalayas used to treat microbial infections. J Pharmacognosy Phytother. 2013;2(4):1-4.

17. Mosmann T. Rapid colorimetric assay for cellular growth and survival: application to proliferation and cytotoxicity assays. J Immunol Methods. 1983;65(1-2):55-63.

18. Denizot F, Lang R. Rapid colorimetric assay for cell growth and survival: modification to the tetrazolium dye procedure giving improved sensitivity and reliability. J Immunol Methods. 1986;89:271-7.

19. Strober W. Trypan blue exclusion test of cell viability. In: Coligan JE, Kruisbeek AM, Margulis DH, Shevach EM, Strober W, editors. Current Protocols in Immunology. New York: John Wiley \& Sons; 1992. p. A.3.3-4

20. Wagner H, Bladt S. Plant Drug Analysis. A Thin Layer Chromatography Atlas. 2nd ed. Müchen: Springer; 1984.

21. Badola HK, Pradhan BK. Plants used in healthcare practices by Limboo tribe in South-West of Khangchendzonga Biosphere Reserve, Sikkim, India. Indian J Tradit Know. 2013:12:355-69.

22. Idrisi MS, Badola HK, Singh R. Indigenous knowledge amd medicinal use of plnts by local communities in Rangit Valley, South Sikkim, India. Ne Bio. 2012;1(2):34-45

23. Chatterjee A. Study on the enraging severity of cancer in West Begal, India from 2003 to 2010. Asian J Epidemiol. 2011;4(1):23-7.
24. Fouche G, Cragg GM, Pillay P, Kolesnikova N, Maharaj VJ, Senabe J. In vitro anticancer screening of South African plants. J Ethnopharmacol. 2008;119:455-61

25. Ramzi AM, Ulrike L, Renate G, Bednarski JP. Studies of the in vitro anticancer, antimicrobial and antioxidant potentials of selected Yemeni medicinal plants from the island Soqotra. BMC Compl Alt Med. 2009;9:7.

26. Fadeyi SA, Fadeyi OO, Adejumo AA, Okoro C, Myles EL. In Vitro Anticancer Screening of 24 Locally Used Nigerian Medicinal Plants. BMC Compl Alt Med. 2013;13:79

27. Mahavorasirikul W, Viyanant V, Chaijaroenkul W, Itharat A, Na-Bangchang K. Cytotoxic activity of Thai medicinal plants against human cholangiocarcinoma, laryngeal and hepatocarcinoma cells in vitro. BMC Compl Alt Med. 2010;10:55.

28. Katrin S. Cytotoxicity of dietary flavonoids on different human cancer types. Pharmacogn Rev. 2014;8(16):122-46.

29. Rashid S, Rather MA, Shah WA, Bhat BA. Chemical composition, antimicrobial, cytotoxic and antioxidant activities of the essential oil of Artemisia indica Willd. Food Chem. 2013;138:693-700.

30. Harun FB, Jamalullail S, Yin K, Othman Z, Tilwari A, Balaram P. Autophagic Cell Death Is Induced by Acetone and Ethyl Acetate Extracts from Eupatorium odoratum In Vitro: Effects on MCF-7 and Vero Cell Lines. Sci World J. 2012;2012:1-9.

31. Singh SA, Singh NR. Antimicrobial activity of Cassia didymobotrya and Phlogacanthus thyrsiformis. J Chem Pharmaceut Res. 2010;2(4):304-8.

32. Mukherjee A, Chaliha M, Das S. Study of analgesic activityof ethanolextract of Phlogacanthus thyrsiformis on experimental animal models. Bangladesh J Pharmacol. 2009:4:147-9.

33. Chakravarty S, Kalita JC. Preliminary phytochemical screening and acute oral toxicity study of the flower of Phlogacanthus thyrsiformis Nees in albino mice. Int Res J Pharm. 2012;3(4):293-5.

34. Pandey AK, Mohan M, Singh P, Palni UT, Tripathi NN. Chemical composition, antibacterial and antioxidant activity of essentialoil of Eupatorium adenophorum Spreng. From Eastern UttarPradesh, India. Food Biosci. 2014;7:80-7.

35. Taylor RSL, Manandhar NP, Hudson JB, Towers GHN. Antiviral activities of Nepalese medicinal plants. J Ethnopharmacol. 1996;52:157-63.

36. Chandrasekhar C, Prabhu KR, Venkateswarlu V. Isolation of a new quinone from Maesa macrophylla. Phytochemistry. 1970;9:415-7.

37. Boik J. Natural Compounds in Cancer Therapy. Minnesota, USA: Oregon Medical Press; 2001

38. Russo M, Spagnuolo C, Tedesco I, Russo GL. Phytochemicals in cancer prevention and therapy: truth or dare? Toxins. 2010;2:517-51.

39. Johann S, Pizzolatti MG, Donnici $C L$, de Resende MA. Antifungal properties of plants used in brazilian traditional medicine against clinically relevant fungal pathogens. Braz J Microbiol. 2007;38:632-7.

40. Jain PK, Joshi H. Coumarin: Chemical and Pharmacological Profile. J Appl Pharmaceut Sci. 2012;2:236-40.

41. Chiang C-T, Way T-D, Tsai S-J, Lin J-K. Diosgenin, a naturally occurring steroid, suppresses fatty acid synthase expression in HER2-overexpressing breast cancer cellsthrough modulating Akt, mTOR and JNK phosphorylation. FEBS Lett. 2007:581:5735-42.

42. Zhang S, Yang X, Morris ME. Flavonoids Are Inhibitors of Breast Cancer Resistance Protein (ABCG2)-Mediated Transport. Mol Pharmacol. 2004;65:1208-16.

43. Bishayee A, Ahmed S, Brankov N, Perloff M. Triterpenoids as potential agents for the chemoprevention and therapy of breast cancer. Front Biosci. 2011;16:980-96.

44. Thakur M, Melzig MF, Fuchs $H$, Weng A. Chemistry and pharmacology of saponins: special focus on cytotoxic properties. Botanics. 2011;1:19-29.

45. Fong HH, Bhatti W, Farnsworth NR. Antitumor activity of certain plants due to tannins. J Pharm Sci. 1972;61:1818. 